\title{
Social Media Marketing Retains Brand Equity During Product Crisis
}

\author{
Kinza Javaid \\ National College of Business Administration \& Economics \\ DHA Campus Lahore, Pakistan \\ Hafsa Amin \\ National College of Business Administration \& Economics \\ DHA Campus Lahore, Pakistan \\ Ahmad Hammad \\ National College of Business Administration \& Economics \\ DHA Campus Lahore, Pakistan \\ Dr. Fareeha Zafar \\ Department of Computer Science \\ Government College University, Lahore. Pakistan
}

\begin{abstract}
The main objective of this study is to explore how social media marketing help brands when brands facings crises. Brand equity is a priceless asset of companies. Most of owners of different businesses say that use of social media do miracles for their businesses. Social media consists of online web interactive tools such as Facebook, YouTube, Google plus, Twitter, Snap chat, Blogs, WhatsApp Etc. Through these tools companies interact with their customers to maintain positive relations with them and to become more close to customers. To support our research we use case study of Maggi Noodles brand in India. In order to accomplish the objective of the study we use Brand Asset Valuator model. The findings of our research shows that social media has positive effect on brand equity during crisis. We also find that where the social media services are not available there are less chances of brand improvement and it has negative effects on brand loyalty and brand equity.
\end{abstract}

Keywords: marketing, brand equity, social media, product crisis

\section{INTRODUCTION}

In the opinion of Social Media Examiner, $92 \%$ of marketers indicate that social media is very significant for their businesses. Mostly the profit-making companies use this social media marketing strategy as a tool in creating brand equity with its products. And company uses brand equity in establishing the customer loyalty/Brand loyalty. In the world of social media, to make your business success full you have to create fast communication and interaction behavior for customers. Social media has changed the way of doing businesses. The changes in doing business over the internet have endorsed the many marketers to embrace the web 2.0 strategies and techniques for their marketing plans. It was quite easy in the era when social media marketing first began to uphold the uniform brand identity. It was a result of few social platforms available at that time. But now the things have changed. There are many different online networks such as Facebook, Social bookmarking sites, Twitter, Yelp, LinkedIn, Blogs, Instagram, Tumbler, YouTube, Pinterest, Google+, and many other social media sites. Through 
these channels companies interact with the users directly and it is different from traditional manner of doing marketing. (Zailskaite-Jakste \& Kuvykaite, 2012).The days are gone when companies tried to depend on high budget Ad campaigns to stay connected with their customers, inducing them that their products are best from their competitors. Nowadays in the world of social media the overall scenario has changed the customer wants, trust and direct relationship with companies. Online availability of brands, distinctly their social presence is valuable in maintaining brand equity, and it adds value to customer awareness. Progressive social media is quite different from traditional marketing because it involves communication, online communities, transparency and availability in every corner of the world. Now companies believe in progressive model of social media for maintaining brand equity (Mccrory, 2015). In the world of brands, word of mouth is most precious technique of social media marketing. In this form of marketing people believe in the words of those people who actually know about those brands not from commercials rather use by themselves (Guren, Osmonbekov, \& Czaplewski, 2006). In this paper we explore how social media marketing helps the companies to retain their brand equity during product crisis.

\section{LITERATURE REVIEW}

There are number of studies conducted on social media importance or role of social media in enhancing the brand equity. One of the studies done by Erdogums, \&Cicek .In their research they find the strong relationship between social media and brand equity. The study shows the positive results that mobile service provider are taking responsibility of social media marketing and users seriously after increasing in the number of user, this will have been increase their better brand equity. This research is based on Impact of social media on consumer buying behavior and brand commitment by using different variables. They find the strong impact of social media on public reaction, brand involvement, brand commitment and buying behavior (Naveed, 2012).Social media gives the lot of opportunities to customers to buy their favorite brands' product from large number of brands list. Online networking sites make it easier for the customers to make their own choice and have direct relationship with brands. This will lead to the brand loyalty and brand commitment (Rehmani \& Khan, 2011).Social media is a platform that enables the customer to share their thoughts, feelings, perceptions and information over the internet by using online working sites. Social media now helps the individuals, companies, brands and governments to share their interest, opinions regarding product and services through these online communities (H., 2010).

\section{MODEL}

The objective of this paper is to describe how social media marketing helps the brands in maintaining their brand equity. It is very challenging for marketers in today's globalized world to be different and must have abilities to deal with market changes. To gain the competitive advantage the marketers and brand managers must create and adopt the constant changes that make their brands different from their competitors.Brand equity is basically associated with your consumer's psychological behavior and knowledge. Brand equity is the consumer belief, awareness about the particular company or its brands. A Model of brand equity called Brand asset valuator that is developed by Advertising agency Young and Rubicam. In order to unique from rest of the brands, these pillars explain the different dimensions a brand needs to be skilful in. According to Brand asset valuator the 4 pillars are as followed in "Fig.1" 


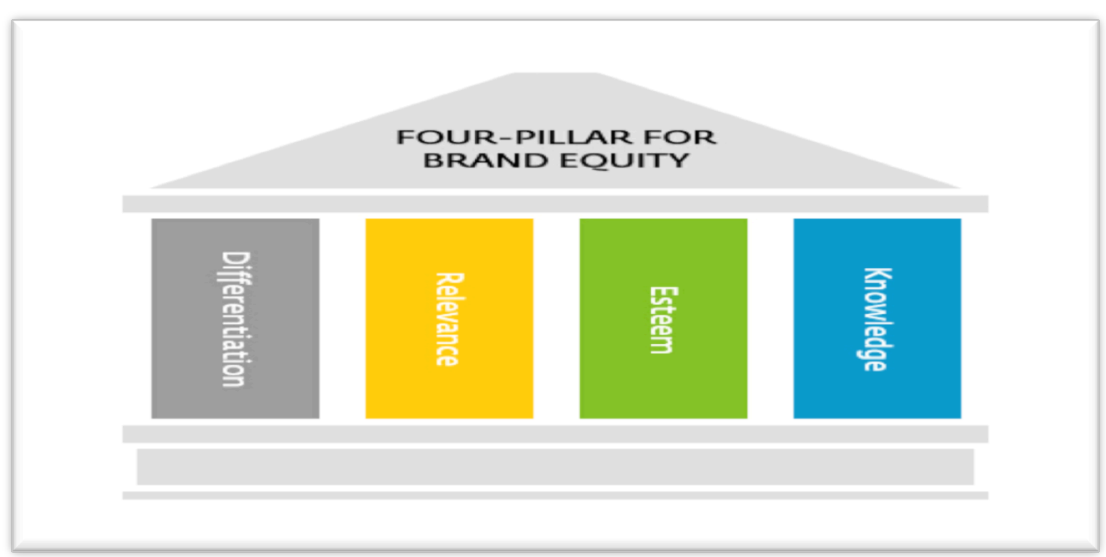

Figure 1

The first pillar of brand equity is differentiation. Differentiation is a brand's ability to look different from other brands. To capture market share and profit you must need to be vigilant in making your brand's key characteristics multidimensional. Brand managers must identify those differentiators that not only make public to find unique but also change their purchasing behavior The differentiation should be purposeful and important for your customers. RELEVANCE is another dimension of brand equity. It is measure of appropriateness. Relevance deals with customers' needs. It defines how purposeful a brand is for their target customer. The first question came in customers mind is 'Does it offer me something? Relevance focuses on the personal needs of the customers regarding a brand. ESTEEM measures how well brand is liked. The degree to which target customer regard for brand. The companies which grow large and doing the business for long time this dimension becomes more significant for them. Due to the social media networks it has change the customer impression. It gives the opportunity to the brands to interact with their customer and get popularity through these networks. KNOWLEDGE means the extent to which customers are associated with the brand. Knowledge is the feature of brand awareness. This dimension identifies the two important points of company, past performance of the brands as well as their further development and innovations. It is very important for the companies to create the brand awareness by developing unique brand name, logo, symbol and tagline. Good understanding and positive knowledge of brand among the potential customer creates the brand loyalty.

Differentiation and Relevance are the components that create Brand strength. It defines the brand's current performance, beliefs, attitude of consumer's mind and their future performance in heavy competition. These 2 components tells the brand's future value rather than past value.

Esteem and Knowledge combines defines Brand stature. It shows the brand's supremacy and signifies the amount to which the brand is respected and how much brand has gained the reputation. Thus, the aim of branding is to basically fully analyze and understand the current situation a brand finds and in order to increase the brands equity then they uses the different and relevant solutions to those problems that they are currently facing.

For getting the complete understanding of current brand situation different brands model are apply to every single pillar. The significance of the different dimensions to each pillar will vary. Two-dimensional plot is apply by brand asset valuator they examine the relationship between the 4 dimensions in the 4 pillars of brand equity model. The brand stature is shown on $\mathrm{x}$-axis and brand strength on Y-axis. This two dimensional power grid defines how brand begins its life. As shown in "Fig.2" 


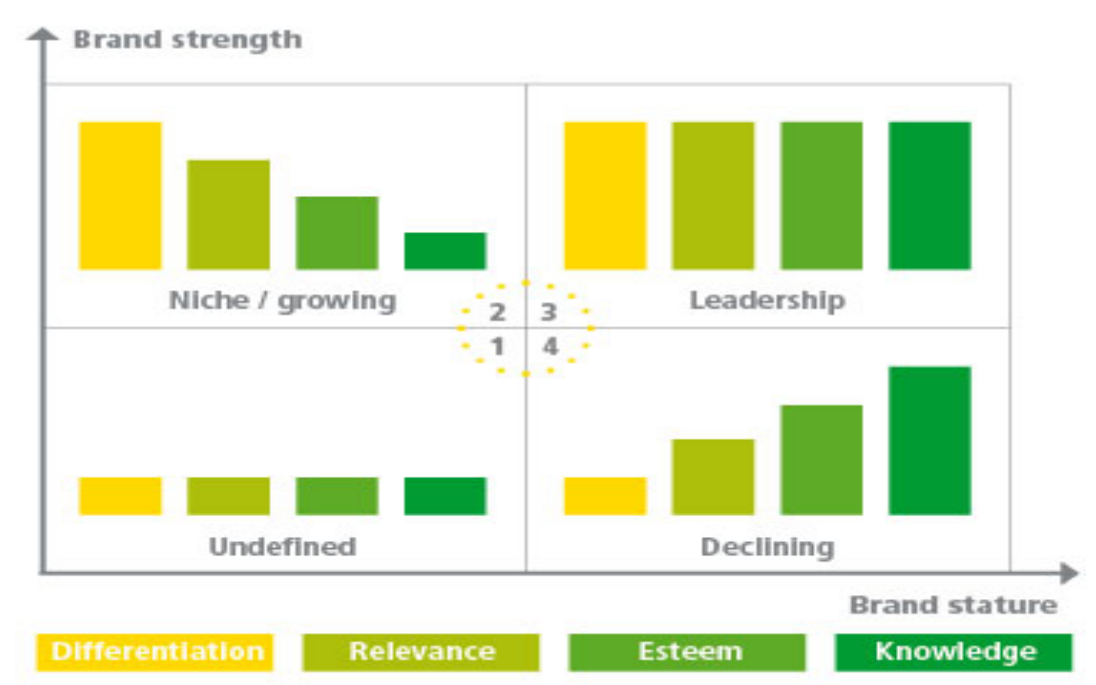

Figure 2

\section{Lower left quadrant}

New Brands usually start their journey in lower left quadrant, in which brand must be different unique and distinctive. Consistent brand differentiations make your brands successful. Brand differentiation is very much important along with other pillars of brand equity. Brand asset valuator identifies that when brand becomes mature the differentiation start decline. This quadrant shows the low strength and low stature.

\section{Top left quadrant}

As the brands Grows, it starts achieving the strength by differentiating themselves from other brands and becoming more relevant to their customer needs. Niche brands emerge in this quadrant .brand strength is remarkably higher than the brand stature.

\section{Upper right quadrant}

Leadership brands are classified by higher brand strength and higher brand stature. To maintain the competitive edge in the market brand have to apply brand management strategies.

\section{Lower right quadrant}

Lower right quadrant in which, brands fail to maintain their brand strength and brand stature. In this quadrant the brands has become distorted from customer's mind. Consumers see the brands unimportant less differentiated less relevance, low esteem and these results losing the customers.

\section{CASE STUDY CONCLUSION}

The lack of apathy by Nestle, in the form of carelessness towards reaching the increased amount of traces of lead beyond the permissible limits in the famous product of Nestle named "Maggi", has resulted into loss of revenue. Due to this fact, only recently, Bombay high court ruled to uplift the ban unless or until Nestle is obliged to perform the testing of five samples from three of the most authentic laboratories of the country in order to confirm that lead amounts have reduced to acceptable levels. However, awareness of this issue amongst the target market have instigated the increase of sales of the counterpart companies and thus, results loss of revenue due to pernicious effect of cheating on the image of Nestle. Nestle Company use social media to interact with their customer on daily bases and response their 
comments regarding this issue .They use social media in a better way to reduce the negative effects on the brand during product crisis. They explain all decisions to customer taken by them during crisis. Maggi noodles use the social media during product crisis in a smart way to encourage their customers keep using the Maggi products.

\section{LIMITATION}

Our study focuses on how social media helps to retain brand equity during the product crises or losses there must be many other factors which can help to improve brand position it may be marketing, offering discount, targeting middle, upper and lower class.

\section{CONCLUSION}

We concluded that where the social media services is available there are $100 \%$ chances of brand improvement by using social media product crises will be deducted by following customer comments. Social media positively influence the brand equity of any brand. Social media popularity depends on the usage of customers which are defined by geographic region. Social media is used to attract customers and keeping customers. Social media is used as communication tool to build long lasting and rewarding relation in market. Social media can used to handle the critical situation in which entrepreneurs become helpless at that time they can take bold step to become the active member of social media can beat the product crises by utilizing the services of social media. And further we analyzed that where brand is facing losses in those geographical regions where there is no social media there is very difficult and very less chances of brand improvement.

\section{References}

Guren, T. W., Osmonbekov, T., \& Czaplewski, A. J. (2006). eWOM: The impact of customer-to-customer online know-how exchange on customer value and loyalty. Journal of Business Research, 59 (4), $449-456$.

Mccrory, K. (2015, February 25). How social media \& technology is changing the way we do business. Retrieved August 14, 2016, from https://www.virgin.com: https://www.virgin.com/virgin-unite/business-innovation/howsocial-media-technology-is-changing-the-way-we-do-business

Naveed, N. (2012). Role of Social Media on Public Relation, Brand Involvement and Brand commitment. Interdisciplinary journal of contemporary research in business, III (9), 904-913.

Rehmani, M., \& Khan, M. I. (2011). The Impact of E-Media on Customer Purchase Intention. International Journal of Advanced Computer Science and Applications, 2 (3), 100-103.

Schau, H. J., Muñiz Jr., A. M., \& Arnould, E. J. (2009). How Brand Community Practices Create Value. Journal of Marketing, 73 (5), 30-51.

Zailskaite-Jakste, L., \& Kuvykaite, R. (2012). Consumer Engagement in Social Media by Building. Electronic International Interdisciplinary Conference, (pp. 194-202). 